\title{
Pelatihan Personal Branding Bagi Persiapan Pengembangan Karir Mahasiswa Tingkat Akhir
}

\author{
Anissa Lestari Kadiyono ${ }^{1 *}$, Gianti Gunawan ${ }^{2}$, Arief Budiarto ${ }^{3}$, Endah Andriani ${ }^{4}$, \\ Medianta $^{5}$ iD \\ ${ }^{I}$ Fakultas Psikologi, Universitas Padjadjaran \\ ${ }^{2}$ Fakultas Psikologi,Universitas Kristen Maranatha \\ ${ }^{3,4}$ Fakultas Psikologi, Universitas Jenderal Achmad Yani \\ ${ }^{5}$ Fakultas Pendidikan, Universitas Pendidikan Indonesia \\ *Corresponding author:anissalestari90@gmail.com
}

\section{Abstract}

Masa pandemi covid-19 meningkatkan pengangguran dan mengancam tenaga kerja baru menjadi Sumber Daya Manusia dikarenakan kurangnya lapangan kerja yang berkualitas. Upaya yang dapat dilakukan oleh Perguruan Tinggi yang akan mencetak mahasiswa sebagai lulusan sarjana yang akan memasuki dunia kerja adalah dengan melakukan intervensi untuk meningkatkan kesiapan mahasiswa menghadapi dunia kerja. Intervensi yang dilakukan berupa program pelatihan dengan pemberian wawasan dan keterampilan yang dibutuhkan untuk meningkatkan kapasitas psikologis mahasiswa yang akan menjadi angkatan kerja baru, khususnya dalam hal Personal Branding. Pemberian program pelatihan dilakukan menggunakan konsep pengembangan karir yang memperhatikan tahap perkembangan karir mahasiswa yang berada pada tahap eksplorasi. Intervensi berupa pelatihan ini dilakukan pada 98 orang mahasiswa dan memberikan dampak positif pada pertambahan wawasan, keterampilan, dan kesiapan mahasiswa dalam memasuki dunia kerja. Hal ini dapat diterapkan pada perguruan tinggi lain untuk meningkatkan kesiapan mahasiswa dalam menghadapi dunia kerja. Pemberian program pelatihan dilakukan menggunakan konsep pengembangan karir yang memperhatikan tahap perkembangan karir mahasiswa yang berada pada tahap eksplorasi. Intervensi berupa pelatihan ini dilakukan pada 98 orang mahasiswa dan kemudian ditemukan bahwa terdapat peningkatan pada post test dibanding dengan pre test. Pemberian program pelatihan secara berkala berhasil meningkatkan kesiapan mahasiswa dalam memasuki dunia kerja dari sisi kesiapan psikologis dalam memasuki dunia kerja.

Keywords: Pelatihan; Personal Branding; Kesiapan Kerja.

\section{Abstract}

During the Covid-19 pandemic, increasing unemployment and threatening new workers to become Human Resources due to a lack of quality jobs. Efforts that can be made by university that will produce students as undergraduate graduates who will enter the world of work are to intervene to increase students' readiness to face the world of work. The intervention was carried out in the training program by providing the insights and skills needed to increase the personal capacity of students who would become a new workforce, especially at personal branding and personal development. Training programs are provided using the concept of career development that takes into account the career development stages of students who are at the exploration stage. It's about 98 students participate at the program that is carried out has a positive impact on increasing students' insights, skills, and readiness to work. This can be applied to other universities to increase students' readiness to face the world of work.

Keywords: Training; Personal Branding; Personal Development; Employability

\section{Introduction}

Upaya mencegah penularan Covid-19 dengan memberlakukan Pembatasan Sosial Berskala Besar (PSBB) meliputi peliburan sekolah dan tempat kerja, pembatasan kegiatan

$\begin{array}{ll}\text { History: } & \\ \text { Received } & \text { : } 02 \text { August } 2020 \\ \text { Revised } & \text { : 09 September } 2020 \\ \text { Accepted } & : 06 \text { October } 2020 \\ \text { Published } & : 30 \text { November } 2020\end{array}$


keagamaan, dan/atau pembatasan kegiatan di tempat atau fasilitas umum. Hal ini meningkatkan penggunaan teknologi sebagai upaya untuk tetap dapat melakukan kegiatan yang tidak dapat dilakukan dengan bertemu secara fisik. Hal ini mempercepat proses adaptasi yang dibutuhkan dalam menghadapi revolusi industri 4.0. Transformasi proses produksi menjadi proses digitalisasi tidak berarti bahwa semua pekerjaan akan terpengaruh secara signifikan. Sebaliknya, masyarakat perlu merespons proses ini dengan lebih dari satu strategi transformasi dan dengan perubahan inovatif (Kurt, 2019; Setiawan, 2017). Di era digital seperti sekarang ini, personal branding menjadi hal yang bisa dilakukan dilakukan. Personal branding menjadi hal penting sebagai cara untuk meningkatkan 'nilai jual' seseorang (Afrilia, 2018). Personal branding merupakan pandangan yang ada dalam diri seseorang tentang bagaimana orang lain dlihat dari segi positifnya dalam menggunakan jasanya (Hakim et al., 2017; Lumban Tobing \& Damayanti, 2016; Salam, 2020; Soraya, 2017). Meski personal branding sudah ada sejak era-era sebelumnya, namun di era digital inilah tahapan personal branding menjadi hal yang begitu umum dilakukan, khususnya melalui internet. Kemajuan teknologi komunikasi meniadakan sekat dan jarak yang membatasi individu satu dan lainnya (Afrilia, 2018; Herawati, 2011). Perguruan Tinggi yang memiliki tugas untuk mendidik mahasiswa menjadi lulusan yang siap mengaplikasikan ilmunya dan memasuki dunia kerja.

Namun situasi pandemic yang dihadapi saat ini membuat tantangan berbeda dengan berkurangnya lapangan pekerjaan dan semakin ketatnya persaingan memasuki dunia kerja. Hal ini juga ditemukan pada salah satu perguruan tinggi di kota Bandung Jawa Barat yang memiliki misi untuk menghasilkan tenaga-tenaga lulusan yang mampu memperkuat perekonomian bangsa dengan menjadi seorang pemimpin-pemimpin yang berjiwa enterpreneur yang mampu mengambil keputusan dengan cepat dan mampu mengaplikasikan ide-ide kreatif. Lulusan diharapkan memiliki employability yakni kesiapan bekerja untuk menghadapi dunia kerja setelah lulus program studi yang ditempuhnya. Dengan menekankan pada keahlian kompetensi melalui pembekalan teori dan penguatan praktek yang selaras dengan kebutuhan dunia kerja maka diperlukan pengembangan terhadap kemampuan intra dan interpersonal dari setiap mahasiswanya. Jika ini tidak tangani dengan baik ini tentunya akan berdampak terhadap jumlah penganguran yang ada. Situasi ini diperparah dengan adanya Covid-19 yang meningkatkan jumlah pengangguran yang ada di Indonesai.

Badan Pusat Statistik (BPS) menyatakan jumlah pengangguran di Indonesia bertambah menjadi 6,88 juta orang pada Februari 2020. Angka ini naik 60.000 orang 0,06 juta orang dibanding periode yang sama dibanding tahun 2019 lalu. Dari tingkat pendidikan, Lulusan SMK menyumbang Tingkat Pengangguran Terbuka (TPT) 8,49\%. Sementara untuk jumlah pengangguran terendah dari pendidikan SD ke bawah sebesar 2,64\%, kemudian SMP 5,02\%, Universitas 5,73\%, SMA 6,77\% dan Diploma I/II/III sebesar 6,76\%. Menteri Ketenagakerjaan Ida Fauziyah memprediksi jumlah pemutusan hubungan kerja (PHK) akibat Covid-19 akan bertambah sekitar 2,92 juta hingga 5,23 juta orang. Menaker menyatakan jumlah pekerja yang terdampak situasi pandemi Covid-19 mencapai 1,7 juta orang, baik pekerja formal maupun informal. Kedua, perubahan lanskap pasar tenaga kerja pasca-krisis. SMERU Research Instute (2020), terdapat potensi perubahan lanskap pasar tenaga kerja pada masa pasca krisis menyebabkan tersingkirnya tenaga kerja berpendidikan dan berketerampilan rendah dari sektor formal. Setidaknya ada empat hal terjadi: (1) Jumlah tenaga kerja yang terkena PHK lebih besar dari penyerapan kerja. (2) Perusahaan hanya akan merekrut tenaga kerja memiliki produktivitas tinggi dan mampu mengerjakan beberapa tugas sekaligus (multitasking). (3) Saat pandemik, teknologi memungkinkan kegiatan ekonomi untuk terus berjalan tanpa bergantung pada interaksi fisik manusia (Khairul Adabi dan Desi Yustari Muchtar, 2017). Jadi di masa depan, tenaga kerja yang dibutuhkan ke depan 
adalah mereka memiliki kemampuan di bidang teknologi. Dan (4) Bagi para pelaku usaha, sistem alih daya (outsourcing) dan pekerja kontrak menjadi lebih menarik. karena keduanya memberikan fleksibilitas tinggi kepada perusahaan dalam hubungannya dengan tenaga kerja.

Oleh karenanya, dibutuhkan proses pengembangan karir bagi mahasiswa tingkat akhir agar memiliki potensi dan kompetensi yang dibutuhkan dalam rangka membentuk diri menjadi SDM Unggul dan berdaya saing. Upaya untuk mengembangkan karir dilakukan menggunakan konsep teori Super, pengembangan karir memberikan penjelasan bahwa individu usia 15-24 tahun berada pada tahap eksplorasi (Agungbudiprabowo et al., 2018). Tahap eksplorasi ditandai dengan mulai melakukan penelaahan diri (self-examination), mencoba membagi berbagai peranan, serta melakukan penjelajahan pekerjaan atau jabatan baik di sekolah, pada waktu senggang, maupun melalui sistem magang (Mansyur et al., 2019). Dengan adanya program coaching yang fokus dalam mengembangkan identitas vokasional (vocational identity) mahasiswa, diharapkan dapat membantu mahasiswa dalam mengembangkan identitias vokasional secara utuh, sehingga terhindar dari kebingungan peran identitas (role confusion) khususnya peran identitas vokasional. Hal ini akan meningkatkan kematangan karir mahasiswa. Kematangan karier adalah sejauh mana individu telah mencapai titik dalam perkembangan kognisi, emosi, dan faktor psikologis lainnya di mana seseorang memiliki kemampuan untuk membuat pilihan yang realistis dan matang (Maslikhah et al., 2019; Winarsih et al., 2014). Semakin matang individu, semakin besar kemungkinan individu membuat keputusan yang bijak, tulus, dan memuaskan berkenaan dengan pilihan karier. Hal ini memungkinkan individu untuk mengatasi tugas perkembangan karier pada berbagai tahap perkembangan karier. Kematangan karier adalah kemampuan untuk membuat pilihan pekerjaan yang sesuai dengan kemampuan individu, minat kerja dan preferensi pekerjaan. Winarsih et al., (2014) telah melakukan penelitian yang luas mengenai remaja, yaitu mengenai kesiapan individu dalam membuat pilihan yang baik. Mereka berasumsi bahwa terdapat perbedaan kematangan karier antar individu, yang mengindikasikan kemampuan mengidentifikasi berbagai komponen kematangan karier. Hal ini dapat dilihat dalam gambar 1 sebagai berikut:

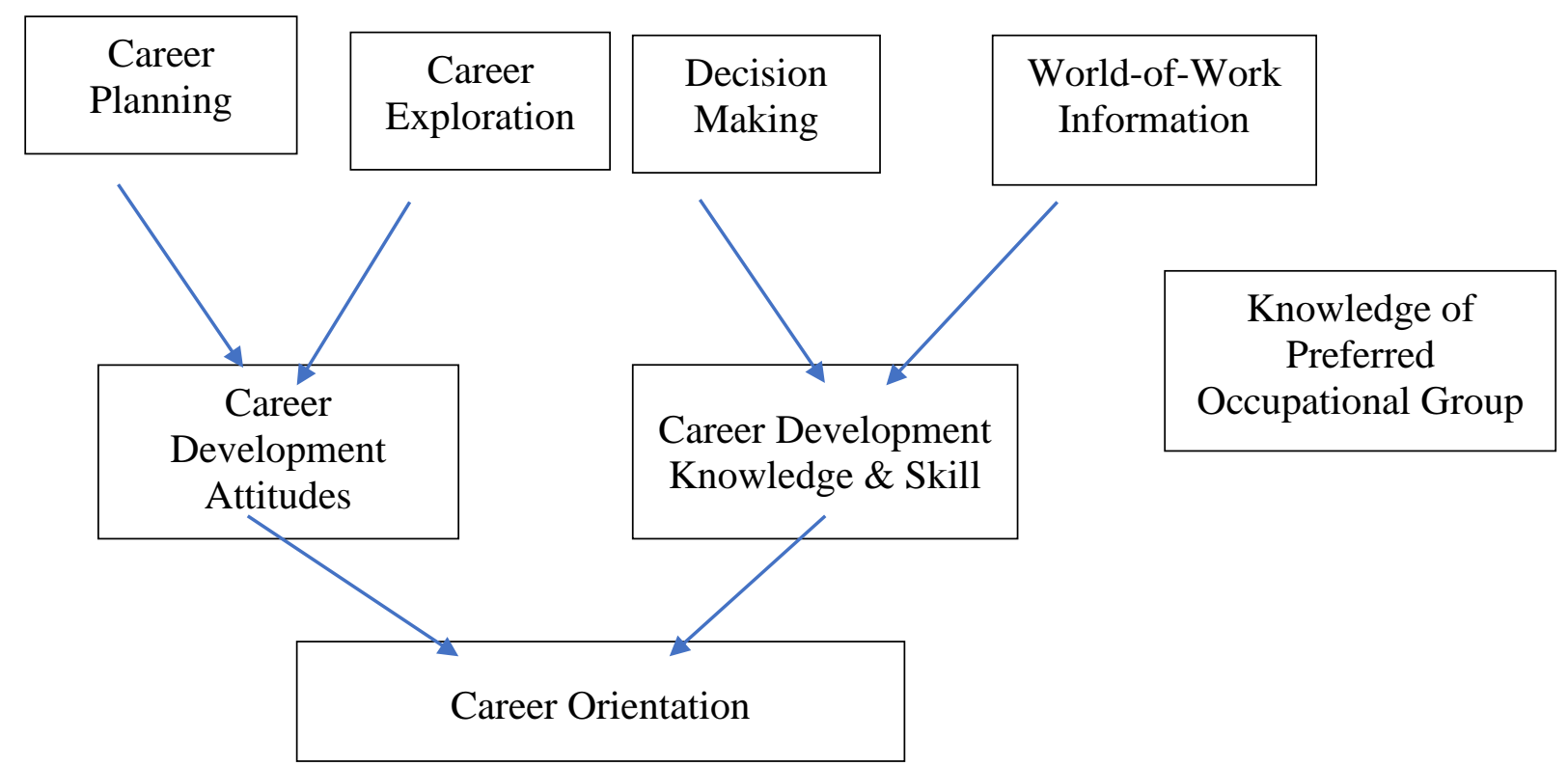

Gambar 1. Orientasi Karir 
Berdasarkan gambaran diatas, maka mahasiswa memerlukan pengisian tahap eksplorasi karir dengan meningkatkan: kemampuan melakukan perencanaan dalam karir, melakukan eksplorasi, mengambil keputusan dan memiliki informasi-informasi yang relevan dalam pengembangan karir. Upaya untuk dapat mengembangkan sikap positif dalam mengembangan karir dan mengembangkan wawasan serta keterampilan yang diperlukan dapat dilakukan melalui intervensi pengembangan karir mahasiswa melalui program pelatihan. Penelitian yang dilakukan oleh Ng \& Feldman (2005) menyebutkan bahwa terdapat beberapa hal yang mempengaruhi kesuksesan seseorang. Hal ini dapat digambarkan dalam model seperti yang tertera dalam gambar 2 sebagai berikut:

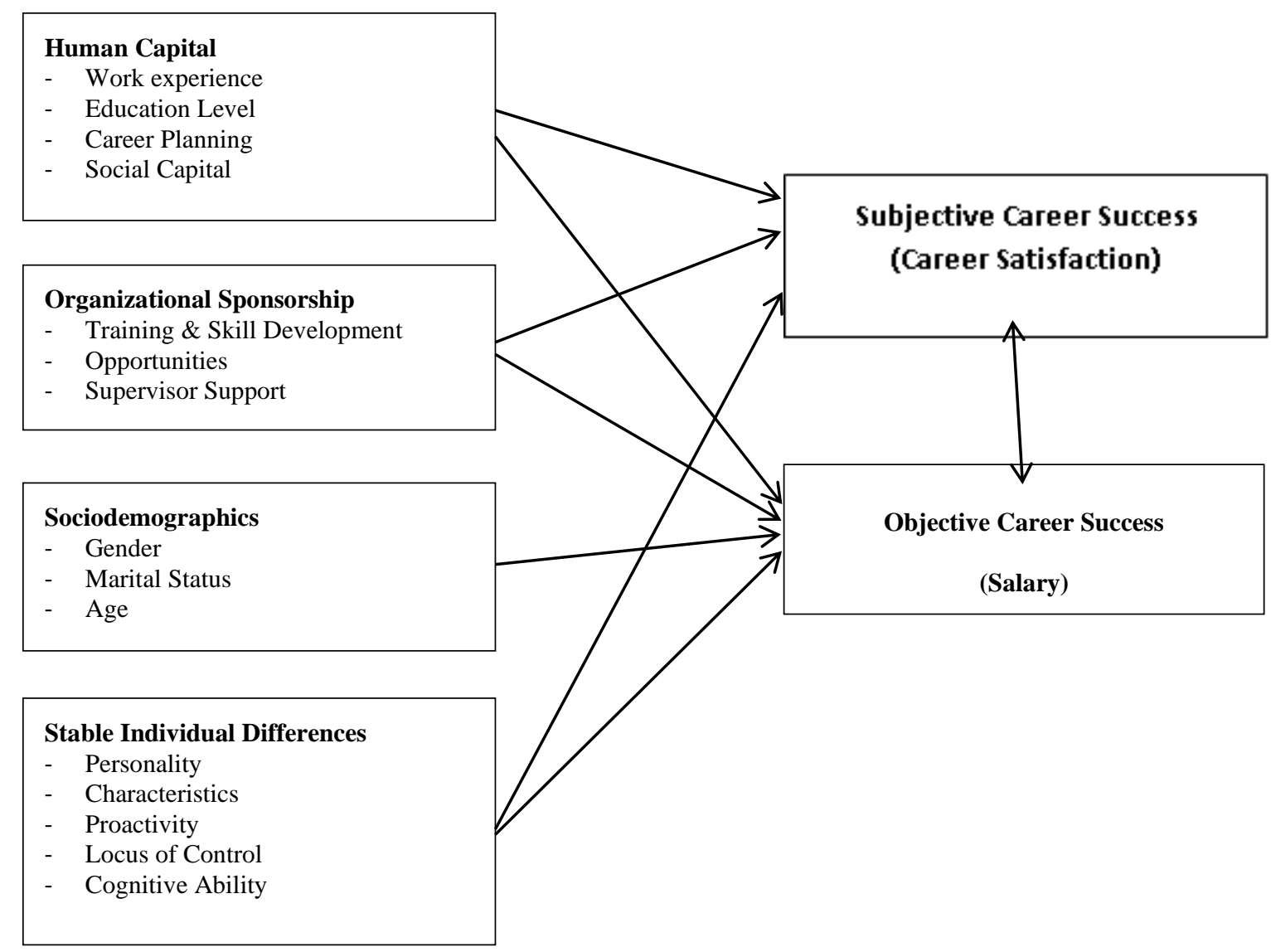

Gambar 2. Prediktor Kesuksesan Karir (Ng \& Feldman, 2005)

Dari sisi dukungan perguruan tinggi selaku organisasi (organizational sponsorship) memiliki sumbangan paling tinggi dalam membentuk kepuasan karir individu. Hal ini dapat dilakukan dalam melakukan pelatihan (training \& skill development). Faktor kedua yang memiliki factor terbesar lainnya adalah perbedaan individu, yang ditandai dengan adanya karakteristik individu yang bersifat unik. Upaya mengembangkan karakteristik individu dalam mengambangkan diri menjadi paaduan terbaik dalam upaya mengembangkan kesiapan kerja mahasiswa. Pengembangan karakteristik pribadi ini dibangun melalui citra diri (personal branding). Dengan demikian, upaya melakukan intervensi berupa pelatihan dapat memberikan kesempatan pada mahasiswa untuk melakukan eksplorasi karir yang dilakukan oleh dirinya sendiri dengan diberikan gambaran dan contoh nyata mengenai dunia kerja dan 
apa yang mau ditampilkan oleh dirinya pada dunia kerja melalui citra diri sehingga dapat lebih siap dalam menghadapi tuntutan di dunia kerja kelak.

\section{Materials and Methods}

Pada Pelatihan dilakukan sebagai intervensi peningkatan kesiapan kerja mahasiswa. Tujuan utama dari program pelatihan ini adalah untuk dapat membuat para mahasiswa ini mampu menjadi pribadi yang lebih baik lagi di masa pandemic covid-19 dan menjadi yang terbaik di bidang yang akan dipilihnya kelak. Topik yang menjadi fokus utama adalah pembangunan citra diri (Personal Branding). Peserta pelatihan adalah 98 orang mahasiswa tingkat akhir pada universitas $\mathrm{X}$ di kota Bandung yang telah mengisi informed consent dan kesediaan untuk mengikuti kegiatan secara penuh. Pelatihan dilakukan secara daring menggunakan platform Webex dan dilakukan selama 15 jam yang dilakukan selama 5 hari (3 jam) selama 5 minggu.

\section{Materi Pelatihan}

Kegiatan yang dilakukan dipetakan dalam table 3 adalah sebagai berikut:

Tabel 1. Kegiatan Pelatihan

\begin{tabular}{|c|c|c|c|}
\hline $\begin{array}{l}\text { Minggu } \\
\text { ke - }\end{array}$ & $\begin{array}{c}\text { Topik } \\
\text { Pelatihan }\end{array}$ & Tujuan & Isi Kegiatan \\
\hline 1 & $\begin{array}{l}\text { Career } \\
\text { Assessment }\end{array}$ & $\begin{array}{l}\text { Memberikan self } \\
\text { awareness } \\
\text { terhadap } \\
\text { pengembangan } \\
\text { karir yang sudah } \\
\text { dimiliki dan hal } \\
\text { apa yang perlu } \\
\text { dikembangkan }\end{array}$ & $\begin{array}{l}\text { Pemahaman mengenai eksplorasi karir yang } \\
\text { dibutuhkan dalam upaya mengembangkan } \\
\text { karir ke depan. Setelah itu dilakukan Career } \\
\text { Assessment yang dilakukan dengan teknik } \\
\text { online test dimana mahasiswa dapat } \\
\text { mengenal diri dari sisi kepribadian, menilai } \\
\text { potensi kewirausahaan dan kesiapan karir } \\
\text { (employability), juga mengetahui kelebihan } \\
\text { maupun kekurangannya untuk selanjutnya } \\
\text { menjadi bahan pengembangan dirinya. }\end{array}$ \\
\hline & Career & $\begin{array}{l}\text { Memberikan } \\
\text { umpan balik atas } \\
\text { pemetaan } \\
\text { perkembangan }\end{array}$ & $\begin{array}{l}\text { Pemahaman akan potensi disi dan tahap } \\
\text { perkembangan karir mahasiswa. Mahasiswa } \\
\text { juga diarahkan untuk dapat memetakan } \\
\text { kompetensi, baik secara hard skill maupun }\end{array}$ \\
\hline 2 & $\begin{array}{l}\text { Assessment } \\
\text { Feedback }\end{array}$ & $\begin{array}{lr}\text { karir } & \text { yang } \\
\text { dimiliki } & \text { oleh } \\
\text { mahasiswa } & \end{array}$ & $\begin{array}{l}\text { soft skill. Dalam kegiatannya, peserta } \\
\text { diberikan workbook agar dapat merinci } \\
\text { seberapa jauh mereka telah melakukan atau } \\
\text { pun belum melakukan hal-hal yang mungkin } \\
\text { menunjang kesiapannya untuk berkarir. }\end{array}$ \\
\hline 3 & $\begin{array}{l}\text { Personal } \\
\text { Branding }\end{array}$ & $\begin{array}{l}\text { Memberi } \\
\text { kesadaran } \\
\text { pentingnya } \\
\text { menarik perhatian } \\
\text { dunia luar pada } \\
\text { diri individu } \\
\text { masing-masing. }\end{array}$ & $\begin{array}{l}\text { Mahasiswa diberikan pemaparan agar dapat } \\
\text { mengenali dan menguasai dirinya masing- } \\
\text { masing sehingga mampu melakukan } \\
\text { branding diri dalam meniti karir, kemudian } \\
\text { diberikan workbook yang sekiranya dapat } \\
\text { membantu mahasiswa mengenali dirinya } \\
\text { lebih dalam dan dapat mencari tahu potensi } \\
\text { dalam diri yang dapat dikembangkannya, }\end{array}$ \\
\hline
\end{tabular}




\begin{tabular}{cccc}
\hline $\begin{array}{c}\text { Minggu } \\
\text { ke }-\end{array}$ & $\begin{array}{c}\text { Topik } \\
\text { Pelatihan }\end{array}$ & Tujuan & \multicolumn{1}{c}{ Isi Kegiatan } \\
\hline & & & $\begin{array}{l}\text { serta potensi lingkungan yang menunjang } \\
\text { usaha mereka dalam melakukan branding. }\end{array}$ \\
\hline
\end{tabular}

\section{Results and Discussion}

Pelatihan Personal Branding dilakukan dengan menggunakan tahapan pelatihan yang dapat dilakukan dalam membangun personal branding di dunia professional (Prickette, McWright, Bishop, \& Moffatt (n.d) sebagai berikut:

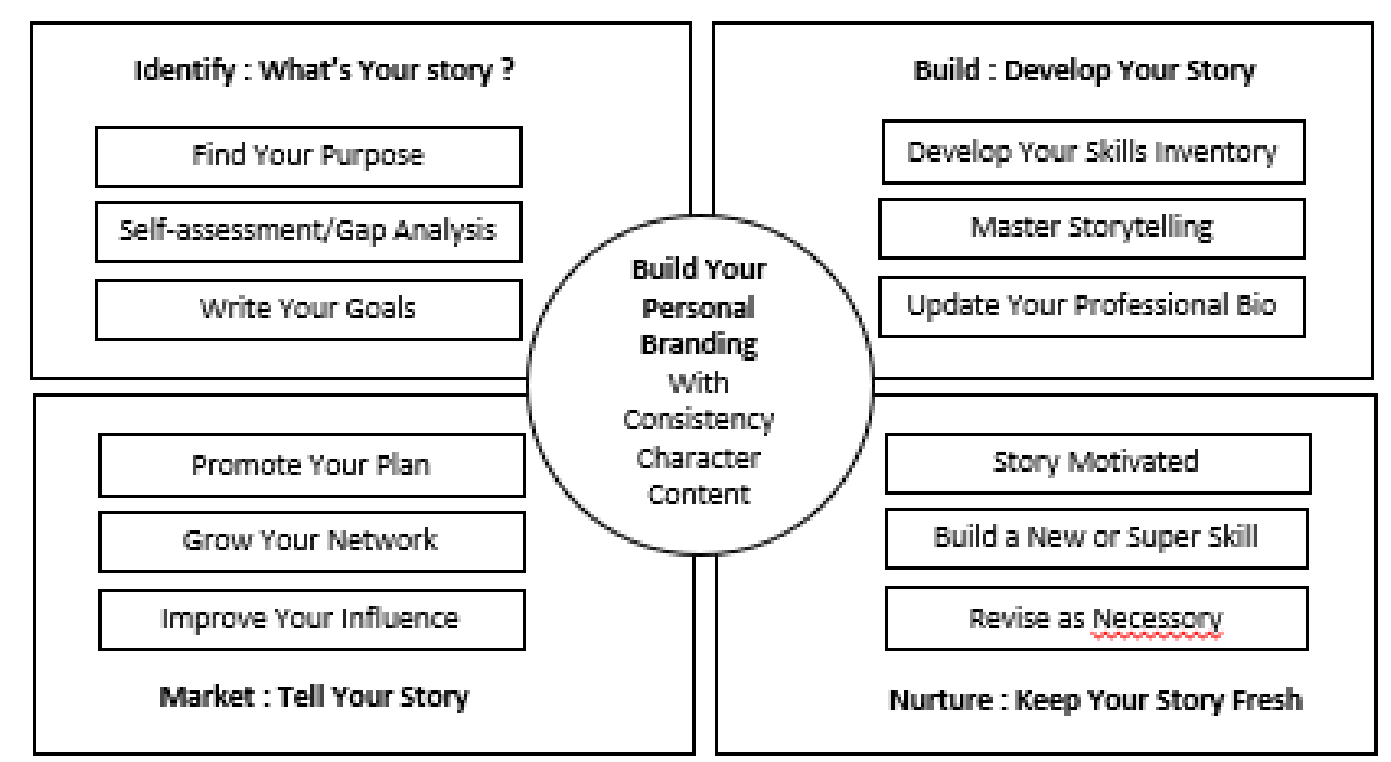

Gambar 3. Tahap Pembangunan Citra Diri

Tahapan pelaksanaannya dilakukan dengan panduan sebagai berikut:

\section{Identifikasi: What's Your Story?}

Tahapan pertama dalam membangun personal branding adalah untuk menemukan keunikan diri. Dalam mengidentifikasi kekuatan dan kelemahan diri, dikenal istilah self awareness. Self awareness melibatkan menyadari berbagai aspek diri termasuk sifat, perilaku, dan perasaan. Pada dasarnya, merupakan keadaan psikologis di mana diri menjadi fokus perhatian. Pada tahapan pertama ini dibagi menjadi langkah-langkah berikut:

Pertama, tentukan tujuan temukan keotentikan dan identifikasi tujuan dalam hidup. Individu yang berorientasi pada tujuan cenderung lebih bahagia dan lebih sukses. Kedua, lengkapi Penilaian Diri. Langkah berikutnya adalah untuk mengevaluasi bagaimana tujuan yang sudag ditentukan dibandingkan dengan kondisi saat ini, baik secara pribadi maupun secara professional. Apakah ada blind spot yang perlu dikoreksi? Dalam melihat blind spot ini, dapat dengan menanyakan pandangan orang lain terhadap diri atau dengan bantuan professional menggunakan self assessment. Menurut APA, melalui self assessment, dapat diidentifikasi kekuatan dan kelemahan, baik secara akademis dan profesional, termasuk minat dan nilai-nilai individu. Ketiga, tuliskan tujuan. Sebelum menyelesaikan tahap identifikasi dalam pengembangan personal branding, individu harus mengkristalkan tujuan dan menentukan tindakan yang akan dicapainya. Tuliskan tujuan secara spesifik dalam hal waktu, di mana dan bagaimana cara mencapainya. Ingatlah untuk menggunakan metode SMART yaitu spesifik, terukur, dapat dicapai, realistis dan terikat waktu. 


\section{Build: Develop Your Story}

Pada tahap ini, individu perlu mengembangkan bukti dan kemudian menampilkannya dengan baik untuk mendapatkan pengakuan di dunia professional yang menunjukkan keterampilan serta minat. Perama, develop inventory skills. Membangun bukti dalam hal keterampilan atau minat, baik secara kualitas maupun kuantitas. Kedua, master storytelling. Keterampilan dan minat dapat disampaikan secara tertulis, lisan atau visual-menggunakan kombinasi elemen untuk memastikan yang menarik dan/atau membantu menyampaikan tujuan. Media sosial dapat membantu mempermudah dalam memperluas koneksi, dan efisien untuk berbagi minat, kegiatan dan prestasi professional. Ketiga, perbarui bio professional. Dokumentasikan pengalaman yang menunjukkan minat profesional. Pastikan judul profil dan pernyataan ringkasan bersifat unik dan relevan. Sangat penting untuk menjelaskan bakat dengan cara yang menarik. Tips lain dalam tahap ini adalah: selalu memiliki foto profesional saat ini. Gunakan foto yang sama pada semua profil media social dan gunakan nama yang sama dan bio yang konsisten di digital platform, misalnya, LinkedIn, asosiasi profesional, database alumni

\section{Market: Tell Your Story}

Pada bagian ini, personal branding individu akan dimunculkan ke dalam tindakan. Tindakan ini terdiri atas, Pertama, promote your plan and grow your digital network. Saat ini, sangat penting untuk mengelola digital personal branding dengan cara membuat, memoles dan secara teratur memerbaruinya dalam rangka memperluas jejaring melalui media sosial. Kedua, grow your network. Network adalah tentang berbagi informasi dan membangun kepercayaan dan hubungan; ini adalah dasar dari hubungan pribadi yang bermakna, sehingga penting dalam memelihara relasi profesional yang sudah dibangun. Ketiga, Improve Your Influence. Hal yang penting dikuasai pada tahap ini adalah komunikasi persuasif. Komunikasi persuasif adalah seni memberi pengaruh kepada orang lain dalam hal kepercayaan, sikap, maupun tindakan.

\section{Nurture: Keep Your Story Fresh}

Jadilah pembelajar seumur hidup, tetap terinformasi dan terinspirasi. Jadilah ulet, bergairah, hormat, dan berkomitmen. Dalam bagian akhir ini, individu diharapkan terus bergerak termotivasi, menggali lebih dalam ke dalam keahliannya, terutama dalam memonitor diri sendiri dan menentukan dalam membuat perubahan atau keluar dari zona nyaman. Yang terdiri atas beberapa tahap yaitu: pertama, stay motivated. Tahap ini memerlukan keterampilan dalam manajemen perubahan. Dibutuhkan waktu dan energi untuk terus membuat perubahan, membuat perilaku baru dan meningkatkan hasil. Kedua, build a new skill. Perbaikan diri perlu terus dilakukan. Pola pikir pertumbuhan membantu kemampuan dasar individu dapat terus dikembangkan. Individu perlu terus membangun portofolio keterampilan dan kekuatan yang dimilikinya. Kedua, revise as necessary. Mencapai keberhasilan adalah kerja keras. Terus mencoba, gagal, terus mencoba, dan akhirnya berhasil. Namun, mungkin ada alasan bahwa sudah waktunya untuk mendefinisikan kembali dan membuat perubahan arah.

Sebagai gambaran dalam rangkaian program pelatihan pada sesi citra diri, setelah menerima materi, peserta diajak untuk melakukan praktek mempresentasikan diri dalam membuat langkah-langkah dalam mempertajam personal brand untuk karir yang lebih baik. Dimulai dari tahap pertama yakni pengisian identitas dimana peserta memberikan nilai yang ia pegang sebagai prinsip hidup, apa saja hal yg dianggap penting, sehingga akan memengaruhi perilaku, cara berkomunikasi, dan berinteraksi dengan orang lain. Nilai ini kemudian akan diturunkan menjadi personal branding yang ingin dibentuk dalam diri peserta. 
Selanjutnya menuliskan tujuan hidup peserta jangka pendek dan jangka panjang, dan mengisi SWOT analisis. Kemudian tahap kedua yang diisi dari membangun personal branding adalah "Build". Bagaimana peserta dapat menunjukkan kemampuannya tersebut hal apa saja yang SUDAH di lakukan dalam rangka mencapai tujuan, dan hal apa yang BELUM di lakukan dalam mencapai tujuan tersebut. Dan tahap yang ketiga atau terakhir adalah melakukan aksi untuk mempromosikan personal brand masing-masing peserta. Dalam kegiatan pelatihan yang telah diselenggarakan, evaluasi kegiatan perlu untuk dilakukan untuk mengetahui sejauhmana kelebihan dan kekurangan dari pelaksanaan kegiatan dan juga akan membantu untuk mengetahui hambatan dan kekurangan selama proses pelaksanaan kegiatan.

\section{Evaluasi Pelatihan Level 1}

Berikut adalah evaluasi pelatihan level 1 yaitu reaksi peserta pelatihan yang telah dilakukan yang dapat dilihat dalam gambar 4.

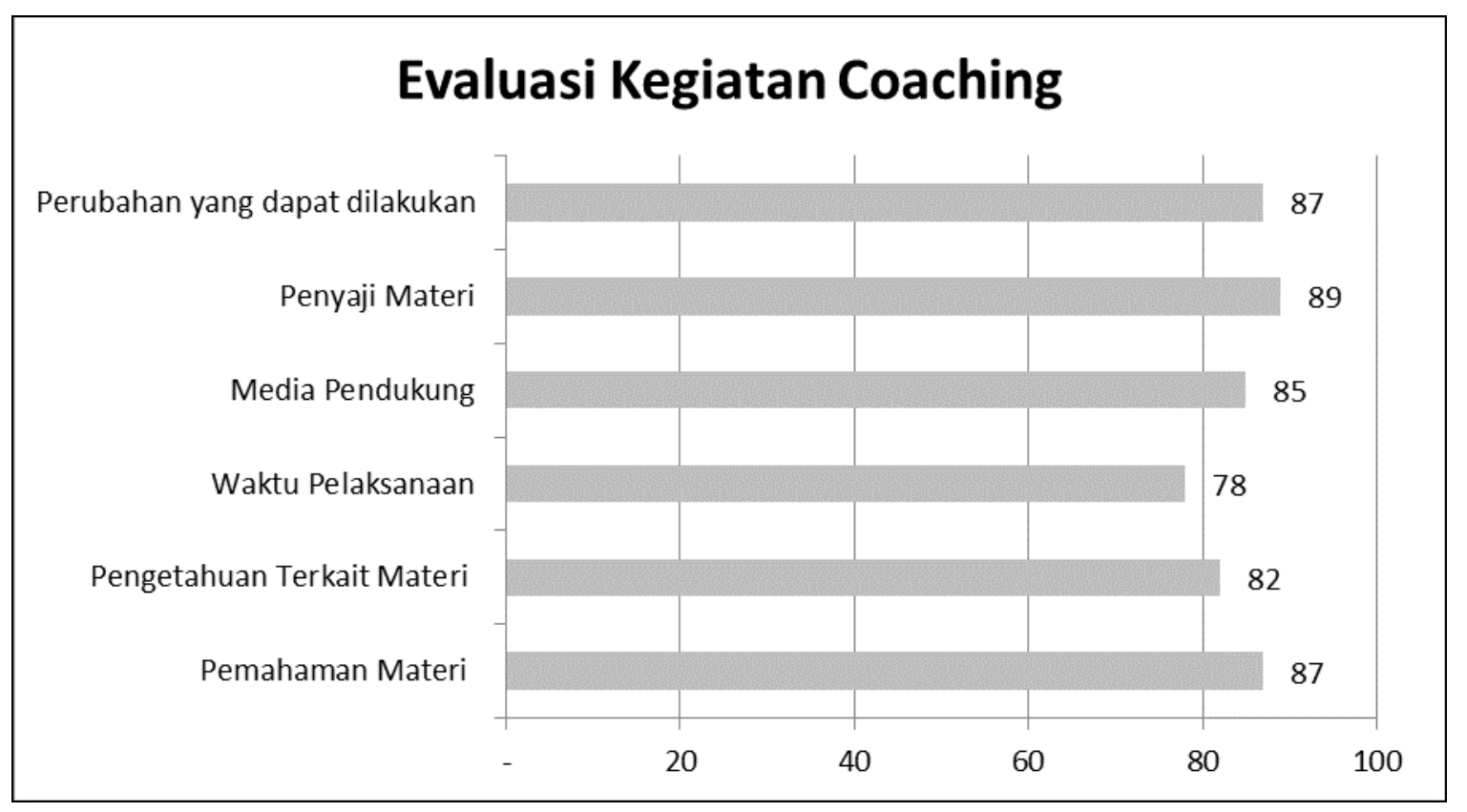

Gambar 4. Evaluasi Pelatihan Level 1 - Reaksi Peserta Pelatihan

Secara umum, program pelatihan dapat diterima dengan baik dan membawa dampak yang positif untuk menambah wawasan, keterampilan, dan kesiapan mahasiswa dalam bekerja. Hal ini akan mendukung upaya yang dapat universitas lakukan untuk meningkatkan kesiapan kerja lulusannya memasuki dunia kerja.

\section{Evaluasi Pelatihan Level 2}

Dalam pelatihan Level 2 ini dilakukan evaluasi proses belajar keterampilan dan sikap untuk menambah pengetahuan. Keberhasilan sebuah pelatihan dapat diukur dengan evaluasi. Oleh karena itu, pada Level ini dilakukan pre-test dan post test untuk mengukur seberapa jauh pengetahuan yang diperoleh dari pelatihan. Evaluasi pelatihan Level 2 disajikan dalam Tabel 2 sebagai berikut. Tabel disajikan dalam bentuk rata-rata per item. 
Tabel 2. Data Pre-Test dan Post Test

\begin{tabular}{clcc}
\hline NO & \multicolumn{1}{c}{ Evaluasi } & $\begin{array}{c}\text { PRE- } \\
\text { TEST }\end{array}$ & $\begin{array}{c}\text { POST- } \\
\text { TEST }\end{array}$ \\
\hline 1 & Pengenalan Kompetensi yang Dibutuhkan Dunia Kerja & 3.92 & 4.38 \\
2 & Alternatif Solusi Dalam Meningkatkan Kompetensi Kerja & 3.75 & 4.25 \\
3 & Kemampuan Menampilkan Diri sebagai Pribadi yang & & \\
& $\begin{array}{l}\text { Dibutuhkan Perusahaan } \\
4\end{array}$ & 3.53 & 4.13 \\
& Pengenalan Kekuatan dan Kelemahan diri sebagai calon & & \\
5 & Tenaga Kerja & 3.67 & 4.00 \\
6 & Pengembangan Keterampilan & 3.48 & 4.13 \\
7 & Pengembangan Pola Pikir & 3.11 & 3.88 \\
8 & Gawasan Permasalahan Diri \& Lingkungan & 3.55 & 4.13 \\
\hline
\end{tabular}

Dari Tabel diatas menunjukkan bahwa hasil evaluasi post test lebih tinggi dibanding pre test. Dilihat dari rata-rata pre test dan post test terdapat peningkatan rata-rata tertinggi terjadi pada item 6 yang membahas tentang cara membangun pola pikir mahasiswa menjadi calon lulusan Perguruan Tinggi. Selain dilihat berdasarkan perhitungan rata-rata per item dapat juga dilakukan analisa statistik menggunakan metode uji t. Metode ini lakukan guna untuk mengetahui apakah ada perbedaan rata-rata yang signifikan antara pre test dan post test. Berdasarkan hasil uji t terlihat $\mathbf{p}=(\mathbf{0 . 0 0 1})<\mathbf{0 . 0 5}$ yang menunjukkan ada perbedaan yang signifikan antara rata-rata pre test dan post test. Sehingga dari uji $\mathrm{T}$ juga menunjukkan adanya peningkatan rata-rata pada post test dibanding dengan pre test. Dari analisa rata-rata per item dan uji-T terbukti bahwa hasil evaluasi pelatihan Level 2 sangat berguna untuk mengetahui dampak pelatihan. Dengan demikian pelatihan memberikan dampak baik dan bermanfaat karena dapat meningkatkan pengetahuan seorang freshgraduate dan dapat tergolong dalam kategori pelatihan yang berhasil. Pemberian program pelatihan secara berkala mengenai citra diri dan pengembangan diri telah berhasil membuat mahasiswa meningkatkan wawasan, pengetahuan, dan keterampilannya dalam memasuki dunia kerja dari sisi kesiapan psikologis sehingga potensial untuk dapat dilanjutkan kembali pada mahasiswa tingkat akhir lainnya, terlebih di masa pandemi sehingga dapat meningkatkan kualitasnya dalam menghadapi tantangan yang lebih tinggi di masa sekarang ini.

Pelatihan didefinisikan sebagai perolehan sistematis dari keterampilan, aturan, konsep, atau sikap yang menghasilkan peningkatan kinerja di suatu lingkungan, pelatihan dapat digunakan sebagai bentuk intervensi untuk peningkatan kinerja (Kristina, 2017; Zipi \& Himam, 2014). Intervensi pengembangan organisasi adalah urutan kegiatan, tindakan, dan peristiwa dimaksudkan untuk membantu organisasi meningkatkannya kinerja dan efektivitas (Sulaefi, 2017). Merancang intervensi atau perencanaan tindakan, berasal dari diagnosis yang cermat dan dimaksudkan untuk menyelesaikan masalah tertentu dan untuk meningkatkan bidang organisasi tertentu berfungsi diidentifikasi dalam diagnosis. Salah satu pendekatan utama pengembangan organisasi, yaitu human process interventions. Intervensi proses manusia bertujuan untuk pencapaian pemenuhan (fulfillment) manusia dan harapan bahwa efektivitas organisasi berangkat dari perbaikan fungsi dari proses organisasi dan proses orang mencapai tujuan organisasi. Yang termasuk dalam pendekatan ini adalah pelatihan, proses konsultasi, team building, coaching, third party intervention (merupakan proses konsultasi yang diarahkan untuk memperbaiki relasi disfungsional dalam organisasi). Selain itu ada bentuk intervensi lebih luas pada organisasi yaitu: Organization confrontation meeting (yaitu menggerakkan anggota organisasi, mengidentifikasi masalah, menetapkan target tindakan, dan mulai menyelesaikan masalah). Intergroup relations (intervensi ini dirancang untuk 
meningkatkan interaksi di antara berbagai kelompok atau departemen dalam organisasi), large group interventions (intervensi melibatkan pemangku kepentingan ke dalam pertemuan besar untuk memperjelas nilai-nilai penting, untuk mengembangkan cara-cara baru, bekerja, mengartikulasikan visi baru untuk organisasi, atau untuk memecahkan masalah mendesak dalam organisasi).

\section{Conclusion}

Telah terjadi kesenjangan antara dunia pendidikan tinggi dan dunia kerja. Perguruan tinggi memandang lulusan yang mempunyai kompetensi tinggi adalah mereka yang lulus dengan nilai tinggi. Sedangkan dunia kerja menganggap bahwa lulusan yang high competence adalah mereka yang mempunyai kemampuan teknis dan sikap yang baik. Hal tersebut menunjukkan bahwa hard skill merupakan faktor penting dalam bekerja, namun keberhasilan seseorang dalam bekerja tidak terlepas dari soft skill yang baik. Situasi pandemi covid-19 yang memberikan efek bertambahnya jumlah pengangguran dan semakin sedikitnya lapangan pekerjaan memberikan dampak diperlukan adanya upaya dari setiap orang untuk dapat mengatasi permasalahan, terutama dari sisi kesiapan kerja baik meningkatkan orientasi berwirausaha atau meningkatkan kemampuannya bekerja melalui peningkatan kapasitas psikologis yang dimiliki oleh individu selaku angkatan kerja. Program pelatihan dapat dilakukan sebagai intervensi untuk meningkatkan kesiapan kerja mahasiswa menjadi lulusan yang siap menghadapi dunia kerja. Pemberian materi berupa asesmen diri, peningkatan citra diri dan pengembangan diri memiliki dampak yang baik terhadap kesiapan mahasiswa dalam memasuki dunia kerja.

\section{References}

Afrilia, A. M. (2018). Personal Branding Remaja di Era Digital. Mediator: Jurnal Komunikasi, 11(1), 20-30. https://doi.org/10.29313/mediator.v11i1.3626

Agungbudiprabowo, A., Nurhudaya, N., \& Budiamin, A. (2018). Efektivitas Program Bimbingan Karir Berbasis Teori Super untuk Mengembangkan Identitas Vokasional Remaja. Jurnal Psikologi Pendidikan Dan Konseling: Jurnal Kajian Psikologi $\begin{array}{lllll}\text { Pendidikan Dan Bimbingan } & \end{array}$ https://doi.org/10.26858/jpkk.v4i1.5725

Hakim, A. Z., Hafiar, H., \& Puspitasari, L. (2017). Personal Branding of Homeschooling Teacher. Eduutech, 16(2), 122-137.

Herawati, E. (2011). Komunikasi Dalam Era Teknologi Komunikasi Informasi. Humaniora, 2(9), 100-109.

Kristina, A. (2017). Model Training Needs Analysis Untuk Membentuk Perilaku Inovatif Sdm Industri Kecil Sepatu Di Jawa Timur. EKUITAS (Jurnal Ekonomi Dan Keuangan), 14(4), 434. https://doi.org/10.24034/j25485024.y2010.v14.i4.2184

Kurt, R. (2019). Industry 4.0 in Terms of Industrial Relations and Its Impacts on Labour Life.
Procedia
Computer
Science,
158
590-601. https://doi.org/10.1016/j.procs.2019.09.093

Lumban Tobing, C. R., \& Damayanti, T. (2016). PERSONAL BRANDING PUTRI DANIZAR SEBAGAI DISC JOCKEY MUDA INDONESIA (Studi Riset Naratif mengenai Personal Branding Putri Danizar Sebagai Disc Jockey Muda Indonesia). Communication, 7(2), 58. https://doi.org/10.36080/comm.v7i2.629

Mansyur, A. I., Chairunnisa, D., \& Hidayat, D. R. (2019). Implementasi Teori Super pada 
Program Layanan Bimbingan dan Konseling Karir untuk Mahasiswa Perguruan Tinggi. JJurnal Psikologi Konseling, 15(2). https://jurnal.unimed.ac.id/2012/index.php/Konseling/article/download/16197/12649

Maslikhah, Hapsyah, D. R., Jabbar, A. A., \& Hidayat, D. R. (2019). Implementasi Teori Donald E. Super Pada Program Layanan BK Karir di SMK. Jurnal Ilmu Dan Budaya, 41(17), 7661-7680. http://journal.unas.ac.id/ilmu-budaya/article/download/716/589

Salam, O. D. (2020). Personal Branding Digital Natives di Era Komunikasi Media Baru (Analisis Personal Branding di Media Sosial Instagram). Business Economic, Communication, and Social Sciences (BECOSS) Journal, 2(1), 19-30. https://doi.org/10.21512/becossjournal.v2i1.6070

Setiawan, W. (2017). Era Digital dan Tantangannya. Seminar Nasional Pendidikan, 1-9.

Soraya, I. (2017). Personal Branding Laudya Cynthia Bella Melalui Instagram (Studi Deskriptif Kualitatif Pada Akun Instagram @Bandungmakuta). Jurnal Komunikasi, 8(2), 30-38. http://ejournal.bsi.ac.id/ejurnal/index.php/jkom/article/view/2654

Sulaefi, S. (2017). Pengaruh Pelatihan Dan Pengembangan Terhadap Disiplin Kerja Dan Kinerja Karyawan. Jurnal Manajemen Dan Kewirausahaan, 5(1). https://doi.org/10.26905/jmdk.v5i1.1212

Winarsih, Baedhowi, \& Bandi. (2014). Pengaruh Tenaga Kerja, Teknologi, Dan Modal Dalam Meningkatkan Produksi Di Industri Pengolahan Garam Kabupaten Pati. Pendidikan Insan Mandir, 3, 88-98.

Zipi, N. P., \& Himam, F. (2014). Pengaruh Pelatihan Membangun Relasi Terhadap Peningkatan Kinerja Tim Karyawan Bpr X Yogyakarta. Jurnal Intervensi Psikologi (JIP), 6(1), 39-50. https://doi.org/10.20885/intervensipsikologi.vol6.iss1.art3 